five direct representatives by the registered medical practitioners in the United Kingdom, while Section 10 , subsection 1, paragrapl $\mathrm{C}$, of the same Act provides the power for returning by the registered medical practitioners additional direct representatives to the General Council. 2. That petitions have been presented to and received by the General Council on November , 1890, urging the General Council to lepresent to the Privy Council that such increase in the number of lirect representatives be provided for, and that the President of the General Council stated the proposal was one which would have to be "actually judged and decided upon by an authority outside and superior to the Conncil itself, to which authority, indeed, it would be more profitably addressed. 3. Your petitioners further beg to state that the registered medical practitioners since 1859 have paid no less than $£ 155,985$ as registration fees, and that the Universities and medical corporations represented on the General Council by twenty representatives do not contribute to the income of the said Council, although their representatives are paid for their services ont of the above income.

4. That in 1875 the number of registered medical practitioners on the Medical Register was 22,715 , while in 1890 the number had increased to 29,163 , thus showing the necessity for an increase in the number of direct representatives.

5. Your petitioners would call your lordships' attention to the valuable help already given to medical education tives on the General Council.

Therefore your petitioners humbly pray that your lordships will exercise the power vested in the Privy Council by Section 19 of the Medical Act of 1886 , and direct that the registered medical practitioners in each of the three parts of the United Kingdom be given by your lordships the power of returning an additional direct representative for each of the three divisions of the United Kingdom. And that effect will be given to the prayer of your petitioners before November, 1801, when the next quinquennial election of direct representatives will tike place.

And your petitioners will ever pray

Name. Qualification.

Full Address.

\section{TERRIBLE VISITATION OF LOCUSTS IN THE PUNJAB.}

To the Editors of THE LANCET.

SrRS,-The enclosed extract from a letter just received from Rawul Pindi is so interesting and so graphically and tersely describes a probable cause of disease, at all events a great pest in another sense, that I send it to you for your next number if you think it worth publishing.

Rawul Pindi, May 25th, 1891.

The Punjab has this year had a terrible visitation of locusts, the worst there has been for many years. An army of about ten miles wide of unfledged locusts was passing through the station for five days. They have, of course, done much damage; but fortunately the crops were so nearly ripe that they were able to be cut in advance of the invasion, but next year a disastrous visitation is anticipated. Nillions $I$ should say have been destroyed in the station of the unfledged insects, so that in many places the smell from the dead bodies is very bad, and in the dismany places the smell from the dead bodies is very bad, and in the disfallen into them. The trains have several times been delayed for some hours by the inability to make way over the greasy masses of locusts hours by the inability to make way over the greasy masses of locusts crushed on the rails. I believe the authorities are thoroughly alarmed, and steps are being taken, it is said, to orgar

I am, Sirs, yours truly,

Wimpole-street, June 15th, 1891.

\section{J. FAYRER.}

\section{A CRUISE IN THE MEDITERRANEAN.}

\section{To the Editors of THE LANCET.}

SiRs,-I have recently returned from a cruise in the Mediterranean in one of the steamers that are advertised to make yachting cruises, and I have derived so much benefit from various trips, in the same vessel, that $I$ am anxious that others should benefit by the same course. I was very much broken down in health when I made my first trip in the early part of last year. Since then I have been again to the Mediterranean, to Norway, the North Cape, and up the Baltic. The sea air, the variety of changes, the pleasant company one meets in the course of these cruises, all tend to the restoration to health of those who have suffered from various causes-from depression of spirits, nervous affections, attended by loss of appetite and want of sufficient sleep. Men coming on board with every appearance of a general break down of their constitutions in a few days begin to pick up, recover their spirits, join in such amusements as can be obtained on boardship, recover their appetites, and again begin to enjoy life, the change in them becoming very marked; and I know no more rapid means of recovery from sickness of any sort as the patient obtains fresh air, enjoys the advantages of change of scene, without undergoing any fatigue, and, when visiting the various ports, has all the advantages of a home, as he returns to the ship to all his comforts, instead of being in an hotel or having to undergo the fatigue of long railway journeys. I think if medical men knew of the great benefits to be derived from these sea trips, they would often advise their patients to seek this form of recovery to health and spirits, instead of sending them long railway journeys to Scotland, or again to the Continent. The amount of bad weather and rough sea is very small while on the trips to Norway. The sailing is entirely in smooth water in the fiords, and the air is most bracing and invigorating. I have derived such great benefit myself from these trips to sea that $I$ am anxious that others should benefit in a like degree, and therefore address myself to you as being the best way of apreading the knowledge of this experience both to medical men and through them to their patients. -I am, Sirs, yours faithfully,

June 15th, 1891

GEorge H. RaY, M.D.,

Surgeon-General (retired)

\section{WHOOPING-COUGH AND MEASLES.}

\section{To the Editors of THE LANCET.}

SrRs, - A few years ago I submitted the question in the medical journals whether whooping-cough ought not to be included in the term "contagious disease," as used in the Public Health Act, and whether persons suffering from the malady were not liable to prosecution under the Act if exposing themselves in public. It was quite clear to me that the time had come for the profession and the public to realise the importance of this question. As it has now been again raised in THE LANCET, it may be allowed me to strengthen your remarks by drawing attention to the mortality caused by whooping-cough, measles, and scarlet fever during the five years 1885-89. It will be seen from the Tables of the Registrar.General's Reports that the mor tality from whonping-cough exceeded that of measles and scarlet fever respectively.

Mortality in England caused by Whooping-cough.

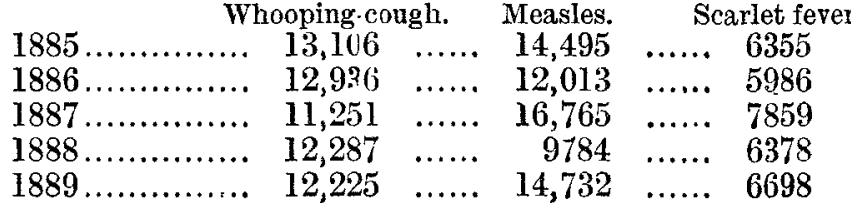

I am disposed to think that a large number of infants die from whooping-cough, whose deaths are attributed to other causes, from the reason I pointed out some years ago, that infants do not whoop.

I am, Sirs, your obedient servant,

Savile-row, W., June 10th, 1891.

ROBERT LEE.

\section{THE HOUSING OF THE WORKING CLASSES IN RURAL DISTRICTS.}

(FROM A CORRESPONDENT.)

THE first inquiry in a rural district under the Housing of the Working Classes Act was held at Ixworth, Suffolk, on Monday last (June 15th), by Lord Francis Hervey, M.P., on behalf of the West Suffolk County Couneil. The formal notice convening the meeting set forth that, the Thingoe Rural Sanitary Anthority having applied to the County Council for a certificate for the adoption of Part III. of the Act, Lord Hervey had been directed to hold a local inquiry, and that all persons interested in the scheme might attend and give evidence. Ixworth is an agricultural village with a population of 951 , and contains 224 inhabited houses (Census, 1891). In an article which recently appeared in a London paper it was stated that "for insanitation and general decay it would be hard to find so many cottages as bad in any rural area in England." This, however, is an exaggeration, for unfortunately there are many villages in which the average dwelling of the agricultural labourer is far inferior to those at Ixworth. It must be admitted that there are many cottages in Ixworth which are really unfit for human habitation-old cottages built of lath and plaster, and covered with straw thatch, both walls and thatch being defective; some with only one bedroom, and that in the roof ; floors of brick, damp and uneven; windows and doors rickety; privies with large cesspools near the houses and the wells; many without gardens and others without back doors. Notwith. 